\title{
molecules
}

ISSN 1420-3049

http://www.mdpi.org

\section{Novel Coumarin Derivatives with Expected Biological Activity}

\author{
Z. M. Nofal*, M. I. El-Zahar and S. S. Abd El-Karim \\ Therapeutical Chemistry Department, National Research Centre, Dokki, Cairo, Egypt \\ Fax: 00202 3370931, E-mail: znofal13@ @otmail.com \\ * Author to whom correspondence should be addressed.
}

Received: 13 August 1999 / Accepted: 20 October 1999 / Published: 16 February 2000

\begin{abstract}
A number of novel 3-bromo-4-methyl-7-methoxy-8-amino substituted coumarins and 2-substituted 7-bromo-6-methyl-8H-pyrano-benzimidazoles, benzoxazoles and/or benzoxazine-8-ones were synthesized for the purpose of pharmacological evaluation. Some representative compounds showed antitumor activity in vitro on Ehrlich ascites carcinoma in the preliminary testing.
\end{abstract}

Keywords: Substituted coumarins, nitro reduction, benzylidinyl amino coumarins.

\section{Introduction}

A review article dealing with the varied physiological activities of coumarin derivatives has been published, describing their anticoagulant, antibacterial, antihelminitic, hypothermal properties and vasodilatatory action [1]. During the last twenty years, the study of the biological activities of coumarin derivatives has been the aim of many researchers [2-5]. Also, the structure activity relationships of coumarins have revealed that the presence of substituted thiocarbonylmercaptoacetylamino derivatives is an essential feature of their pharmacological action. Based on these findings, we describe the synthesis of some compounds featuring different heterocyclic rings fused onto the coumarin moiety with the aim of obtaining more potent pharmacologically active compounds.

(C) 2000 by MDPI (http://www.mdpi.org). Reproduction is permitted for noncommercial purposes. 


\section{Results and Discussion}

The nitration of 3-bromo-7-hydroxy-4-methyl coumarin using concentrated nitric acid and sulphuric acid at $0^{\circ} \mathrm{C}$ gave 3-bromo-7-hydroxy-4-methyl-8-nitro coumarin (1a) and 3-bromo-7-hydroxy-4methyl-6-nitro coumarin (1b) [5]. The separation of these two isomers was carried out by column chromatography using silica gel, and the mixture of nitration products was eluted first with petroleum ether/benzene (1:1) to isolate the 6-nitro isomer, then using methanol to isolate the 8-nitro isomer (Scheme 1).

The ${ }^{1} \mathrm{H}$-NMR spectrum $\left(\mathrm{CDCl}_{3}\right)$ of the 8-nitro isomer (1a) showed signals at $2.4 \mathrm{ppm}\left(3 \mathrm{H}, \mathrm{s}, \mathrm{CH}_{3}\right)$, at 6.80 and $7.00 \mathrm{ppm}(2 \mathrm{H}, \mathrm{dd}$, aromatic protons, $\mathrm{J}=10 \mathrm{~Hz})$ and at $12.05 \mathrm{ppm}(1 \mathrm{H}, \mathrm{s}, \mathrm{OH})$, whereas the ${ }^{1} \mathrm{H}-\mathrm{NMR}$ spectrum (DMSO- $\mathrm{d}_{6}$ ) of compound (1b) showed the same signals except for the aromatic protons at 6.90 and $8.30 \mathrm{ppm}(2 \mathrm{H}$, ss, aromatic protons). Also, the IR spectra of either (1a) or (1b) showed characteristic bands at $1730 \mathrm{~cm}^{-1}$ (lactone $\mathrm{C}=\mathrm{O}$ ) and at $3400 \mathrm{~cm}^{-1}(\mathrm{OH})$.<smiles>Cc1c(Br)c(=O)oc2cc(O)ccc12</smiles>

\section{Scheme 1.}

The methylation of 1a by methyl iodide in the presence of anhydrous potassium carbonate afforded 3-bromo-7-methoxy-4-methyl-8-nitro coumarin (2), which was reduced using powdered iron and concentrated hydrochloric acid to give 8-amino-3-bromo-7-methoxy-4-methyl coumarin (3) (Scheme 1).

The ${ }^{1} \mathrm{H}-\mathrm{NMR}$ of (2) in $\mathrm{CDCl}_{3}$ showed signals at $2.6 \mathrm{ppm}\left(3 \mathrm{H}, \mathrm{s}, \mathrm{CH}_{3}\right), 4.00 \mathrm{ppm}\left(3 \mathrm{H}, \mathrm{s}, \mathrm{OCH}_{3}\right)$ and at 7.20-7.60 ppm ( $2 \mathrm{H}$, dd, aromatic protons, $\mathrm{J}=10 \mathrm{~Hz})$. The IR of $(3)$ showed characteristic bands at $3470 \mathrm{~cm}^{-1}$ to $3440 \mathrm{~cm}^{-1}$ due to presence of the amino group. Also, the mass spectrum of $\mathbf{3}$ showed a molecular ion $\left(\mathrm{M}^{+)}\right.$at $\mathrm{m} / \mathrm{z} 283.0(100 \%)$ and $285.0(94 \%)$ due to the bromine isotopes.

One of the most interesting biologically active side chains is the acetamido group [6], which was introduced by the reaction of amino derivative 3 with chloroacetylchloride in dry benzene. The product 3-bromo-8-chloroacetamido-7-methoxy-4-methyl coumarin (4) was isolated and its structure was confirmed by ${ }^{1} \mathrm{H}-\mathrm{NMR}$ which showed signals at $2.60 \mathrm{ppm}\left(3 \mathrm{H}, \mathrm{s}, \mathrm{CH}_{3}\right), 3.90 \mathrm{ppm}\left(3 \mathrm{H}, \mathrm{s}, \mathrm{OCH}_{3}\right), 4.35$ ppm $\left(2 \mathrm{H}, \mathrm{s}, \mathrm{CH}_{2}\right), 7.20$ and $7.85 \mathrm{ppm}(2 \mathrm{H}, \mathrm{dd}$, aromatic protons, $\mathrm{J}=10 \mathrm{~Hz})$ and at $9.70 \mathrm{ppm}(1 \mathrm{H}, \mathrm{s}$, $\mathrm{NH})$.

In addition, compound 4 was allowed to react with different ammonium salts of substituted dithiocarbamates [7] afforded 3-bromo-7-methoxy-4-methyl-8-substituted thiocarbonylmercaptoacetylamino coumarins (5a-d). The mass spectrum of 5a showed the expected molecular ion peak $\left(\mathrm{M}^{+}\right)$at 
$\mathrm{m} / \mathrm{z} 472.0$ and 474.0. Also, the ${ }^{1} \mathrm{H}-\mathrm{NMR}\left(\mathrm{CDCl}_{3}\right)$ of 5a showed signals at $2.5 \mathrm{ppm}\left(3 \mathrm{H}, \mathrm{s}, \mathrm{CH}_{3}\right), 1.4$ ppm (6H, t, $2 \mathrm{CH}_{3}$ of ethyl group), $4.0 \mathrm{ppm}\left(3 \mathrm{H}, \mathrm{s}, \mathrm{OCH}_{3}\right), 3.5 \mathrm{ppm}\left(4 \mathrm{H}, \mathrm{q}, 2 \mathrm{CH}_{2}\right.$ of ethyl group), 6.9 and $7.5 \mathrm{ppm}(2 \mathrm{H}, \mathrm{dd}$, aromatic protons, $\mathrm{J}=10 \mathrm{~Hz})$ and at $8.6 \mathrm{ppm}(1 \mathrm{H}, \mathrm{s}, \mathrm{NH})($ Scheme 2).<smiles>COc1ccc2c(C)c(Br)c(=O)oc2c1[N+](C)=O</smiles>

7<smiles>Cc1c(Br)c(=O)oc2c([N+](=O)[O-])c(O)ccc12</smiles>

1a<smiles>COc1ccc2c(C)c(Br)c(=O)oc2c1[N+](=O)[O-]</smiles>

2<smiles>COc1ccc2c(C)c(Br)c(=O)oc2c1N=Cc1ccccc1</smiles>

8

\section{$\mathrm{C}_{2} \mathrm{H}_{5} \mathrm{NCS}$}<smiles>CCCc1cc(OC)c(NC(=S)NCC)c2c(C)c(Br)c(=O)oc12</smiles><smiles>COc1ccc2c(C)c(Br)c(=O)oc2c1NC(=O)O</smiles>

$\mathrm{R}_{2} \mathrm{NH} / \mathrm{CS}_{2} / \mathrm{NH}_{4} \mathrm{OH}$<smiles>COc1ccc2c(C)c(Br)c(=O)oc2c1NC(=O)Cl</smiles>

4

5

$\mathrm{a} ; \mathrm{R}=-\mathrm{N}\left(\mathrm{C}_{2} \mathrm{H}_{5}\right)_{2}$

$\mathrm{b} ; \mathrm{R}=-\mathrm{N}$

$\mathrm{c} ; \mathrm{R}=-\sqrt{\mathrm{N}} \mathrm{O}$

$\mathrm{d} ; \mathrm{R}=-\mathrm{N}$

Scheme 2. 
The mass spectrum of $\mathbf{5 c}$ showed molecular ion peak $\mathrm{M}^{+}$at $\mathrm{m} / \mathrm{z} 486$ and 488 . The IR spectrum of 5c showed characteristic bands at $3280 \mathrm{~cm}^{-1}(\mathrm{NH}), 1720 \mathrm{~cm}^{-1}$ (lactone $\mathrm{C}=\mathrm{O}$ ), $1600 \mathrm{~cm}^{-1}$ (NHCO) and at $1550 \mathrm{~cm}^{-1}(\mathrm{C}=\mathrm{S})$.

The product of acetylation of amino derivative $\mathbf{3}$ depends upon the reaction conditions. Using acetic anhydride in presence of acetic acid gave the monoacetyl derivative 6, while the use of excess acetic anhydride only afforded the diacetyl derivative 7. The ${ }^{1} \mathrm{H}-\mathrm{NMR}$ spectrum $\left(\mathrm{CDCl}_{3}\right)$ of 6 showed signals at $2.2 \mathrm{ppm}\left(3 \mathrm{H}, \mathrm{s}, \mathrm{COCH}_{3}\right), 2.6 \mathrm{ppm}\left(3 \mathrm{H}, \mathrm{s}, \mathrm{CH}_{3}\right), 3.90 \mathrm{ppm}\left(3 \mathrm{H}, \mathrm{s}, \mathrm{OCH}_{3}\right), 6.85 \mathrm{ppm}(1 \mathrm{H}$, broad $\mathrm{NH})$ and at 6.95 and $7.55 \mathrm{ppm}\left(2 \mathrm{H}\right.$, dd, aromatic protons). The ${ }^{1} \mathrm{H}-\mathrm{NMR}$ spectrum $\left(\mathrm{CDCl}_{3}\right)$ of 7 showed signals at $2.15 \mathrm{ppm}\left(3 \mathrm{H}, \mathrm{s}, \mathrm{COCH}_{3}\right), 2.25 \mathrm{ppm}\left(3 \mathrm{H}, \mathrm{s}, \mathrm{COCH}_{3}\right), 2.60 \mathrm{ppm}\left(3 \mathrm{H}, \mathrm{s}, \mathrm{CH}_{3}\right), 3.90 \mathrm{ppm}(3 \mathrm{H}$, $\left.\mathrm{s}, \mathrm{OCH}_{3}\right)$ and at 6.95 and $7.70 \mathrm{ppm}(2 \mathrm{H}$, dd, aromatic protons, $\mathrm{J}=10 \mathrm{~Hz})$.

Moreover, the pharmacological activity of some Schiff's bases [8,9] led us to condense 3 with benzaldehyde to get 8-(benzylidinyl)amino-3-bromo-7-methoxy-4-methyl coumarin (8). The mass spectrum of $\mathbf{8}$ showed molecular ion peak $\left(\mathrm{M}^{+}\right)$at $\mathrm{m} / \mathrm{z} 371$ and 373 . The IR of $\mathbf{8}$ showed bands at $1722 \mathrm{~cm}^{-1}$ (lactone $\mathrm{C}=\mathrm{O}$ ) and at $1620 \mathrm{~cm}^{-1}(\mathrm{C}=\mathrm{N})$. On the other hand, the reaction of 3 with ethyl isothiocyanate afforded N-ethyl-N'-[3-bromo-7-methoxy-4-methylcoumarin-8-yl] thiourea (9). The mass spectrum of 9 showed the expected molecular ion peak $\left(\mathrm{M}^{+}\right)$at $\mathrm{m} / \mathrm{z} 371 \& 373$. The IR spectrum of 9 showed characteristic bands at $3400 \mathrm{~cm}^{-1}(\mathrm{NH}), 1720 \mathrm{~cm}^{-1}$ (lactonic $\mathrm{C}=\mathrm{O}$ ) and at $1580 \mathrm{~cm}^{-1}$ (NH-C=S) (c.f. Scheme 2).

3-Bromo-7-hydroxy-4-methyl-8-nitro coumarin (1a) was reduced by using a mixture of iron powder and conc. hydrochloric acid gave the corresponding 8-amino-3-bromo-7-hydroxy-4-methyl coumarin (10). The mass spectrum of 10 showed expected molecular ion peak $\left(\mathrm{M}^{+}\right)$at $\mathrm{m} / \mathrm{z} 268.9$ and 270.9. Also IR showed bands at $3100 \mathrm{~cm}^{-1}\left(\mathrm{NH}_{2}\right)$ and broad band at $3340 \mathrm{~cm}^{-1}(\mathrm{OH})$. As it has been reported that some imidazole and oxazole derivatives have shown biological activity [10], one of the aims of this work was the introduction of these heterocycle ring onto the parent coumarin derivatives. The condensation of amino derivative 10 with thiourea afforded 2-amino-7-bromo-6-methyl-8Hpyrano[2,3-e]benzimidazol-8-one (11) through the liberation of hydrogen sulphide gas, while with urea it afforded 7-bromo-6-methyl-8H-pyrano[3,2-e]benzoxazol-2,8-dione (12) with evolution of ammonia gas. The mass spectrum of $\mathbf{1 1}$ showed the expected molecular ion peak $\left(\mathrm{M}^{+}\right)$at $\mathrm{m} / \mathrm{z} 294$ and 296.0. The IR spectrum of 11 showed characteristic bands at $1720 \mathrm{~cm}^{-1}$ (lactone $\mathrm{C}=\mathrm{O}$ ), $3500 \mathrm{~cm}^{-1}(\mathrm{NH})$ and at 3100-3300 $\mathrm{cm}^{-1}\left(\mathrm{NH}_{2}\right)$. The mass spectrum of 12 showed expected molecular ion peak $\left(\mathrm{M}^{+}\right)$at $\mathrm{m} / \mathrm{z}$ 295.0 and 297.0. The IR spectrum of 12 showed characteristic bands at $1650 \mathrm{~cm}^{-1}$ (NHCO), $1720 \mathrm{~cm}^{-1}$ (lactone $\mathrm{C}=\mathrm{O})$ and at $3420 \mathrm{~cm}^{-1}(\mathrm{NH})($ Scheme 3).

Derivatives containing an oxazole moiety fused onto the coumarin can be synthesized by condensation of amino derivative $\mathbf{1 0}$ with either acid anhydrides (acetic, malic, succinic, phthalic and/or o-nitrophthalic anhydride) or with aldehydes (benzaldehyde, p-nitrobenzaldehyde, p-methoxybenzaldehyde, thiophene-2-carboxaldehyde, p-N,N-dimethylaminobenzaldehyde and/or 3,4,5-trimethoxybenzaldehyde) to give 7-bromo-6-methoxy-2-substituted-8H-pyrano[2,3-e]benzoxazol-8-ones (13a-e and 13f-k) respectively. The mass spectrum of 13a showed the expected molecular ion peak $\left(\mathrm{M}^{+}\right)$at $\mathrm{m} / \mathrm{z}$ 
293 and 295. The IR spectrum of $\mathbf{1 3 b}$ showed characteristic bands at $1620 \mathrm{~cm}^{-1}(\mathrm{C}=\mathrm{N}), 1720 \mathrm{~cm}^{-1}$ (lactone $\mathrm{C}=\mathrm{O}$ ), at $1700 \mathrm{~cm}^{-1}$ (acid $\mathrm{C}=\mathrm{O}$ ) and at $3300 \mathrm{~cm}^{-1}$ (acid $\mathrm{OH}$ ). Also the mass spectrum of 13d showed the expected molecular ion peak $\left(\mathrm{M}^{+}\right)$at $\mathrm{m} / \mathrm{z} 398.9$ and 400.5. The ${ }^{1} \mathrm{H}-\mathrm{NMR}$ spectrum (DMSO) of $\mathbf{1 3 d}$ showed signals at $2.60 \mathrm{ppm}\left(3 \mathrm{H}, \mathrm{s}, \mathrm{CH}_{3}\right), 7.10$ and $7.90 \mathrm{ppm}(2 \mathrm{H}$, dd, coumarin protons) at $7.95-8.10 \mathrm{ppm}(4 \mathrm{H}, \mathrm{m}$, aromatic protons $)$ and at $11.30 \mathrm{ppm}(1 \mathrm{H}$, broad $\mathrm{OH})$. The mass spectrum of $13 f$ showed expected molecular ion peak $\left(\mathrm{M}^{+}\right)$at $\mathrm{m} / \mathrm{z} 355$ and 357 . Also, the IR spectrum of $13 f$ showed characteristic bands at $1620 \mathrm{~cm}^{-1}(\mathrm{C}=\mathrm{N})$, and at $1720 \mathrm{~cm}^{-1}$ (lactone $\mathrm{C}=\mathrm{O}$ ). The mass spectrum of $\mathbf{1 3 h}$ showed the expected molecular ion peak $\left(\mathrm{M}^{+}\right)$at $\mathrm{m} / \mathrm{z} 385$ and 387 . Also for $\mathbf{1 3 \mathbf { j }}$ at $\mathrm{m} / \mathrm{z} 398$ and 400 and for 13k at m/z 445 and 447, respectively.

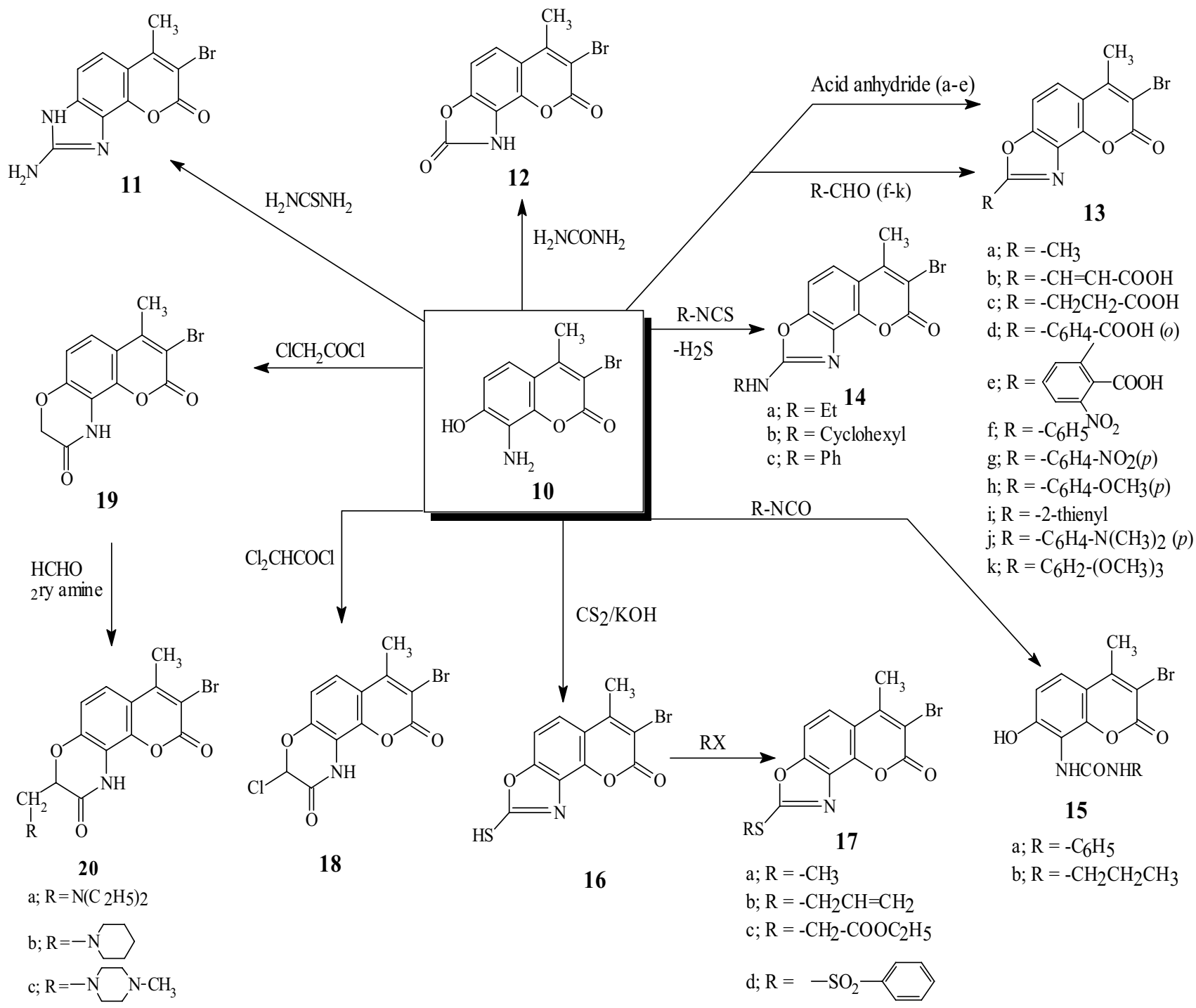

Scheme 3.

Moreover, the condensation of amino derivative $\mathbf{1 0}$ with some isothiocyanates, namely ethyl, cy- 
clohexyl and/or phenyl isothiocyanate afforded 2-substituted amino-7-bromo-6-methyl-8H-pyrano[2,3e]benz-oxazol-8-ones (14a-c), respectively through a cyclocondensation reaction with elimination of hydrogen sulphide gas. The mass spectrum of $\mathbf{1 4 a}$ showed the expected molecular ion peak $\left(\mathrm{M}^{+}\right)$at $\mathrm{m} / \mathrm{z} 322.0$ and 324.0. Also, the ${ }^{1} \mathrm{H}-\mathrm{NMR}$ spectrum $\left(\mathrm{CDCl}_{3}\right)$ of $\mathbf{1 4 a}$ showed signals at $1.35 \mathrm{ppm}(3 \mathrm{H}, \mathrm{t}$, $\left.\mathrm{CH}_{2} \underline{\mathrm{CH}}_{3}\right), 2.60 \mathrm{ppm}\left(3 \mathrm{H}, \mathrm{s}, \mathrm{CH}_{3}\right), 3.60 \mathrm{ppm}\left(2 \mathrm{H}, \mathrm{q}, \underline{\mathrm{CH}_{2}} \mathrm{CH}_{3}\right)$, broad signal at $6.05 \mathrm{ppm}(1 \mathrm{H}, \mathrm{NH})$ and at 7.20 and $7.30 \mathrm{ppm}(2 \mathrm{H}$, dd, aromatic protons). The IR spectrum of $\mathbf{1 4 b}$ showed characteristic bands at $1610 \mathrm{~cm}^{-1}(\mathrm{C}=\mathrm{N}), 1730 \mathrm{~cm}^{-1}$ (lactone $\mathrm{C}=\mathrm{O}$ ) and at $3200 \mathrm{~cm}^{-1}(\mathrm{NH})$ (Scheme 3).

The ${ }^{1} \mathrm{H}-\mathrm{NMR}$ spectrum $\left(\mathrm{CDCl}_{3}\right)$ of $\mathbf{1 4 c}$ showed signals at $2.65 \mathrm{ppm}\left(3 \mathrm{H}, \mathrm{s}, \mathrm{CH}_{3}\right), 4.60(1 \mathrm{H}$, broad, $\mathrm{NH})$ and at 7.00-7.70 ppm $(7 \mathrm{H}, \mathrm{m}$, aromatic protons $)$. The mass spectrum of $\mathbf{1 4 c}$ showed the expected molecular ion peak $\left(\mathrm{M}^{+}\right)$at $\mathrm{m} / \mathrm{z} 370$ and 372.0.

In contrast with the condensation of isothiocyanates, the amino derivative $\mathbf{1 0}$ condensed with phenyl isocyanate and propyl isocyanate without cyclization to give disubstituted ureas, namely $\mathrm{N}$ phenyl (or propyl) -N`-[3-bromo-7-hydroxy-4-methyl coumarin-8-yl] urea (15a,b) respectively. The structure of 15a was confirmed by its mass spectrum that showed a molecular ion peak $\left(\mathrm{M}^{+}\right)$at $\mathrm{m} / \mathrm{z}$ 388 and 390. The structure of $\mathbf{1 5} \mathbf{b}$ was confirmed by its mass spectrum that showed the molecular ion peak $\left(\mathrm{M}^{+}\right)$at $\mathrm{m} / \mathrm{z} 354$ and 356. Also, the ${ }^{1} \mathrm{H}-\mathrm{NMR}$ spectrum of compound $\mathbf{1 5 b}\left(\mathrm{CDCl}_{3}\right)$ showed signals at $1.00 \mathrm{ppm}\left(3 \mathrm{H}, \mathrm{t}, \mathrm{CH}_{2} \underline{\mathrm{CH}}_{3}\right), 1.6 \mathrm{ppm}\left(2 \mathrm{H}, \mathrm{t}, \underline{\mathrm{CH}}_{2} \mathrm{CH}_{3}\right), 2.6 \mathrm{ppm}\left(3 \mathrm{H}, \mathrm{s}, \mathrm{CH}_{3}\right), 3.25 \mathrm{ppm}(2 \mathrm{H}, \mathrm{t}$, $\left.\mathrm{NHCH}_{2}\right), 6.5 \mathrm{ppm}(1 \mathrm{H}$, broad, $\mathrm{NH}), 6.95-7.40 \mathrm{ppm}(2 \mathrm{H}$, dd, aromatic protons, $\mathrm{J}=10 \mathrm{~Hz}), 7.75 \mathrm{ppm}$ $(1 \mathrm{H}, \mathrm{s}, \mathrm{NH})$ and at $12.00 \mathrm{ppm}(1 \mathrm{H}, \mathrm{s}, \mathrm{OH})$.

Also, oxazole thione could be incorporated onto the coumarin ring through cyclocondensation of amino derivative $\mathbf{1 0}$ with carbon disulphide in the presence of potassium hydroxide to give 7-bromo-6methyl-8H-pyrano[2,3-e]benzoxazol-8-one-2-thione (16). This structure was established by the IR spectrum, which showed characteristic bands at $3200 \mathrm{~cm}^{-1}(\mathrm{NH}), 1710 \mathrm{~cm}^{-1}$ (lactone $\mathrm{C}=\mathrm{O}$ ) and at 1180 $\mathrm{cm}^{-1}(\mathrm{C}=\mathrm{S})$. The mass spectrum of compound $\mathbf{1 6}$ showed expected molecular ion peak $\left(\mathrm{M}^{+}\right)$as base peak at $\mathrm{m} / \mathrm{z} 311$ and 313 (Scheme 3).

The thiol derivative 16 was allowed to react with different alkyl halides, namely methyl iodide, allyl chloride, chloroethyl acetate and/or benzene sulphonyl chloride to give 7-bromo-6-methyl-2substituted mercapto-8H-pyrano[2,3-e]benzoxazol-8-ones (17a-d). The ${ }^{1} \mathrm{H}-\mathrm{NMR}$ spectrum $\left(\mathrm{CDCl}_{3}\right)$ of 17a showed signals at $1.50 \mathrm{ppm}\left(3 \mathrm{H}, \mathrm{s}, \mathrm{CH}_{3}-\mathrm{S}\right), 2.6 \mathrm{ppm}\left(3 \mathrm{H}, \mathrm{s}, \mathrm{CH}_{3}\right)$ and at 7.35 and $7.55 \mathrm{ppm}(2 \mathrm{H}$, $\mathrm{dd}$, aromatic protons). Also the ${ }^{1} \mathrm{H}-\mathrm{NMR}$ spectrum $\left(\mathrm{CDCl}_{3}\right)$ of $\mathbf{1 7 c}$ showed signals at $1.3 \mathrm{ppm}(3 \mathrm{H}, \mathrm{t}$, $\left.\mathrm{CH}_{2} \underline{\mathrm{CH}}_{3}\right), 2.6 \mathrm{ppm}\left(3 \mathrm{H}, \mathrm{s}, \mathrm{CH}_{3}\right), 4.30 \mathrm{ppm}\left(2 \mathrm{H}, \mathrm{q}, \underline{\mathrm{CH}_{2}} \mathrm{CH}_{3}\right), 4.15 \mathrm{ppm}\left(2 \mathrm{H}, \mathrm{s}, \mathrm{CH}_{2}-\mathrm{S}\right)$ and at 7.40 and $7.55 \mathrm{ppm}(2 \mathrm{H}$, dd, aromatic protons, $\mathrm{J}=10 \mathrm{~Hz})$. The mass spectrum $17 \mathrm{c}$ showed the expected molecular ion peak $\left(\mathrm{M}^{+}\right)$which is the base peak, at $\mathrm{m} / \mathrm{z} 397$ and 399. Also, the mass spectrum of 17d showed the expected molecular ion peak $\left(\mathrm{M}^{+}\right)$at $\mathrm{m} / \mathrm{z} 451$ and 453 .

On the other hand, this work also aimed to incorporate the oxazine moiety onto the coumarin ring to get more biological active with less toxicity and so the amino derivative $\mathbf{1 0}$ was allowed to react with 
dichloroacetyl chloride and/or chloroacetyl chloride in dry acetone to give 8-bromo-3-chloro-7methyl-9[H]pyrano[2,3-e]benzo-1,4-oxazin-2,9-dione (18) and 8-bromo-7-methyl-9H-pyrano[2,3-e]benzo-1,4-oxazine-2,9-dione (19), respectively (Scheme 3).

The IR spectrum of compound 18 showed characteristic bands at $3240 \mathrm{~cm}^{-1}(\mathrm{NH}), 1700 \mathrm{~cm}^{-1}$ (lactone $\mathrm{C}=\mathrm{O})$ and at $1620 \mathrm{~cm}^{-1}(\mathrm{NHCO})$. The ${ }^{1} \mathrm{H}-\mathrm{NMR}$ spectrum $\left(\mathrm{CDCl}_{3}\right)$ showed signals at $2.6 \mathrm{ppm}(3 \mathrm{H}$, $\left.\mathrm{s}, \mathrm{CH}_{3}\right), 6.20 \mathrm{ppm}(1 \mathrm{H}, \mathrm{s}, \mathrm{CH}-\mathrm{Cl}), 7.00$ and $7.50 \mathrm{ppm}(2 \mathrm{H}$, dd, aromatic protons, $\mathrm{J}=10 \mathrm{~Hz})$ and at 9.5 ppm $(1 \mathrm{H}, \mathrm{s}, \mathrm{NH})$. The ${ }^{1} \mathrm{H}-\mathrm{NMR}$ spectrum of $\mathbf{1 9}\left(\mathrm{d}_{6}\right.$-acetone) showed signals at $2.6 \mathrm{ppm}\left(3 \mathrm{H}, \mathrm{s}, \mathrm{CH}_{3}\right)$, $4.70 \mathrm{ppm}\left(2 \mathrm{H}, \mathrm{s}, \mathrm{CH}_{2}\right), 7.00$ and $7.50 \mathrm{ppm}(2 \mathrm{H}$, dd, aromatic protons) and at $10.00 \mathrm{ppm}(1 \mathrm{H}$, broad, $\mathrm{NH})$. The mass spectrum 19 showed the expected molecular ion peak $\left(\mathrm{M}^{+}\right)$and $\mathrm{m} / \mathrm{z} 309.0$ and 311 (which is the base peak) (Scheme 3).

It is evident that the presence of a basic side chain in the drug may overcome the water insolubility problem [11]. Also hydrochloride formation may render the drug more easily absorbed. Accordingly the oxazine derivative 19 was allowed to undergo a Mannich reaction using different secondary amines, namely diethylamine, piperidine and/or methylpiprazine in the presence of paraformaldehyde to give the corresponding 8-bromo-7-methyl-3-substituted 9H-pyrano-1,4-oxazine-2,9-dione Mannich bases (20a-c), respectively.

The mass spectra of 20a-c showed the expected molecular ion peaks $\left(\mathrm{M}^{+}\right)$at $\mathrm{m} / \mathrm{z} 394.5$ and 396.5; $\mathrm{m} / \mathrm{z} 406$ and 408 and at m/z 421.2 and 423.1, respectively.

The ${ }^{1} \mathrm{H}-\mathrm{NMR}$ spectrum $\left(\mathrm{CDCl}_{3}\right)$ of compound $20 \mathrm{c}$ showed signals at $2.3 \mathrm{ppm}\left(3 \mathrm{H}, \mathrm{s}, \mathrm{N}-\mathrm{CH}_{3}\right), 2.1$ $2.4 \mathrm{ppm}\left(10 \mathrm{H}, \mathrm{m}, 4 \mathrm{CH}_{2}\right.$ of piperazine moeity and $\left.\mathrm{CH}_{2}-\mathrm{N}\right), 2.5 \mathrm{ppm}\left(3 \mathrm{H}, \mathrm{s}, \mathrm{CH}_{3}\right.$ of coumarin ring $), 4.6$ ppm $(1 \mathrm{H}, \mathrm{t}$, of piperazine ring $), 7.00 \mathrm{ppm}(2 \mathrm{H}, \mathrm{dd}$, aromatic protons $)$ and $10.0 \mathrm{ppm}(1 \mathrm{H}, \mathrm{s}, \mathrm{NH})$ (Scheme 3).

\section{Biological Screening}

Some of the prepared compounds 1a, 4, 5a, 6, 8, 12, 14a, 15a, 17a and 20b were tested in vitro on Ehrlich ascites carcinoma. The experiments were done using Ehrlich ascites carcinoma cell (E. A. C.) cultured in RPMI 1640 media at $37^{\circ} \mathrm{C}$ in humidified $5 \% \mathrm{CO}_{2}$ atmosphere in a special tissue culture room using the trypan blue exclusion test $[12,13]$

A line of Ehrlich ascites carcinoma (E.A.C.) was used in this study. The parent line was supplied through the courtesy of Dr. C. Benkijsen, A.V.L. Amesterdam, Holland (1982). The tumour was maintained in the National Research Centre in female Swiss albino mice by weekly intraperitoneal (I.P.) transplanation of $2.5 \times 10^{6}$ cells. The tumour was characterized by a moderately rapid growth which killed mice in about 14-15 days due to accumulation of ascitic fluid and sometimes distal metastasis or spontaneous regression. The results of antitumour screening of selected new compounds is summarized below (Table 1). 
Table 1.

\begin{tabular}{|c|c|}
\hline Compound No. & \% of dead tumour cells at $\mathbf{1 0 0} \boldsymbol{\mu g} / \mathbf{m l}$ \\
\hline $\mathbf{1}$ & $20 \%$ \\
$\mathbf{4}$ & All alive \\
$\mathbf{5 a}$ & $30 \%$ \\
$\mathbf{6}$ & All alive \\
$\mathbf{8}$ & $20 \%$ \\
$\mathbf{1 2}$ & $10 \%$ \\
$\mathbf{1 4 a}$ & All alive \\
$\mathbf{1 5 a}$ & $40 \%$ \\
$\mathbf{1 7 a}$ & All alive \\
$\mathbf{2 0 b}$ & All alive \\
\hline
\end{tabular}

It is clear from the tabulated results that compound 15a is the most active promising compound, while compounds $4,6,14 a, 15 a, 17 a$, and $20 b$ showed no activity.

\section{Experimental}

Melting points were taken on Electrothermal capillary melting point apparatus and are uncorrected. The microanalyses were done at Faculty of Science, Cairo University. Infrared spectra were recorded on a Beckmann FT/IR3303, using KBr disks. ${ }^{1} \mathrm{H}-\mathrm{NMR}$ spectra were recorded on JEOL EX-270 MHz NMR Spectrometer. Mass spectra were recorded on a Finnigan Mat SSQ-7000 mass spectrometer.

\section{3-Bromo-7-hydroxy-4-methyl-8-nitrocoumarin (1a)}

A mixture of 3-bromo-7-hydroxy-4-methyl coumarin [5] (5.1 gm, 0.02 mole) and concentrated sulphuric acid $(30 \mathrm{ml})$ was stirred at $0^{\circ} \mathrm{C}$ for 15 minutes. Then a mixture of concentrated nitric acid $(1.5$ $\mathrm{ml}, \mathrm{d}$ 1.4) and sulphuric acid $(5 \mathrm{ml}, 98 \%)$ was added. The temperature was kept at $0-5^{\circ} \mathrm{C}$ during the period of addition, and the mixture was then continuously stirred for 2 hours at $5^{\circ} \mathrm{C}$. The reaction mixture was poured into ice/cold water, the precipitate formed was filtered and dried, then purified by column chromatography using silica gel eluting with petroleum ether/benzene $(1: 1)$ to isolate the 6nitro isomer, then using methanol to isolate 8-nitro isomer (cf. Table 2).

\section{3-Bromo-7-methoxy-4-methyl-8-nitrocoumarin (2)}

A mixture of coumarin derivative (1a) $(6.0 \mathrm{gm}, 0.02$ mole), methyl iodide (14 ml, 0.22 mole), anhydrous potassium carbonate $(7.0 \mathrm{gm}, 0.05$ mole) and dry acetone $(100 \mathrm{ml})$ was refluxed for 24 hours. The reaction mixture was cooled and poured into ice/cold water, the precipitate formed was filtered 
off, dried and recrystallized (cf. Table 2).

\section{8-Amino-3-bromo-7-methoxy-4-methylcoumarin (3)}

Iron powder ( $4 \mathrm{gm})$ was added portionwise to a mixture of 2 (3.14 gm, 0.01 mole), concentrated hydrochloric acid $(15 \mathrm{ml})$ and ethanol $(10 \mathrm{ml})$. The reaction mixture was refluxed for 6 hours, cooled, the precipitate formed was filtered off, washed with water, dried and recrystallized (cf. Table 2).

\section{3-Bromo-8-chloroacetamido-7-methoxy-4-methylcoumarin (4)}

A mixture of 3 (0.57 gm, 0.002 mole) and chloroacetyl chloride $(0.17 \mathrm{ml}, 0.002$ mole $)$ in dry benzene $(20 \mathrm{ml})$ was refluxed for 3 hours. The reaction mixture was cooled and the precipitate formed was filtered off, washed with dry benzene and crystallized (cf. Table 2).

\section{3-Bromo-7-methoxy-4-methyl-8[ substituted thiocarbonylmercaptoacetyl amino]coumarins (5a-d)}

A solution of the ammonium salt of the appropriate substituted dithiocarbamic acid [7] (0.001 mole) in dry acetone was added while stirring to a suspended of 4 ( $0.36 \mathrm{gm}, 0.001 \mathrm{~mole})$ in dry acetone. Stirring was continued for 30 minutes at room temperature. The reaction mixture was then refluxed for 15 hours, cooled, the precipitate formed was filtered off and recrystallized (cf. Table 2).

\section{8-Acetylamino-3-bromo-7-methoxy-4-methylcoumarin (6)}

Acetic anhydride $(0.19 \mathrm{ml}, 0.002$ mole $)$ was added rapidly to a boiling solution of $3(0.28 \mathrm{gm}, 0.001$ mole) in glacial acetic acid $(3 \mathrm{ml})$. After refluxing for 2 hours, the reaction mixture was cooled and poured into ice/cold water. The precipitate formed was filtered off and recrystallized (cf. Table 2).

\section{8-Bromo-8-diacetylamino-7-methoxy-4-methylcoumarin (7)}

A mixture of 3 (0.57 gm, 0.002 mole) and acetic anhydride (1.8 gm, 0.02 mole) was heated at $100^{\circ} \mathrm{C}$ for 5 hours. After cooling, the reaction mixture was poured into ice/cold water, the precipitate formed was filtered off and crystallized (cf. Table 2).

\section{3-(Benzylidinyl)amino-3-bromo-7-methoxy-4-methyl-coumarin (8)}

A mixture of 3 ( $0.57 \mathrm{gm}, 0.002$ mole $)$ and benzaldehyde $\left(1 \mathrm{ml}, 0.01\right.$ mole) was heated at $200^{\circ} \mathrm{C}$ for 8 hours, the reaction mixture was cooled then treated with ether. The precipitate formed was filtered off and crystallized (cf. Table 3). 


\section{N-Ethyl-N`-[3-bromo-7-methoxy-4-methylcoumarin-8-yl]thiourea (9)}

A mixture of 3 ( $0.57 \mathrm{gm}, 0.002$ mole $)$ and ethylisothiocyanate $(1.77 \mathrm{ml}, 0.02$ mole $)$ was heated at $110-120^{\circ} \mathrm{C}$ for 6 hours. After cooling, the reaction mixture was treated with ether and the precipitate formed was filtered off and crystallized (cf. Table 3 ).

\section{8-Amino-3-bromo-7-hydroxy-4-methylcoumarin (10)}

Iron powder ( $8 \mathrm{gm})$ was added portionwise with stirring to a hot mixture of 1a ( $6 \mathrm{gm}, 0.02 \mathrm{~mole})$ in ethyl alcohol $(20 \mathrm{ml})$ and concentrated hydrochloric acid $(30 \mathrm{ml})$ at reflux temperature. After completion of the addition, the refluxing was continued for 6 hours. Upon cooling a white precipitate formed, which was filtered off, washed with water, dried and recrystallized (cf. Table 3).

\section{2-Amino-7-bromo-6-methyl-8H-pyrano[2,3-e]benzimidazol-8-one (11)}

A mixture of $10(0.57 \mathrm{gm}, 0.002$ mole $)$ and thiourea $(2.28 \mathrm{gm}, 0.03$ mole $)$ was heated at $130-140^{\circ} \mathrm{C}$ for 15 minutes, the reaction mixture melted and resolidified, treated with hot water, filtered off and recrystallized (cf. Table 3).

\section{4-Bromo-6-methyl-8H-pyrano[2,3-e]benzoxazole-2,8-dione (12)}

A mixture of 10 (0.57 gm, 0.002 mole) and urea (1.8 gm, 0.03 mole) was heated at $100^{\circ} \mathrm{C}$ for 15 minutes, the reaction mixture melted and resolidified, treated with hot water. The precipitate was filtered off and recrystallized (cf. Table 3).

\section{7-Bromo-6-methyl-2-substituted-8H-pyrano[2,3-e]benzoxazol-8-ones (13a-e)}

To a solution of $\mathbf{1 0}(0.57 \mathrm{gm}, 0.002$ mole $)$ in pyridine $(10 \mathrm{ml})$, an appropriate acid anhydride $(0.002$ mole), namely, acetic anhydride, maleic anhydride, succinic anhydride, phthalic anhydride and/or onitrophthalic anhydride was added. The reaction mixture was refluxed for 10 hours, the pyridine was distilled under reduced pressure, the residue was washed with water and dissolved in sodium hydroxide solution $(5 \%, 10 \mathrm{ml})$. The reaction mixture was filtered off and neutralized by dilute hydrochloric acid. The precipitate formed was filtered off, washed with water, dried and recrystallized (cf. Table 3).

\section{7-Bromo-6-methyl-2-substituted-8H-pyrano[2,3-e]benzoxazol-8-one (13f-k)}

To a solution of $\mathbf{1 0}(0.57 \mathrm{gm}, 0.002$ mole $)$ in glacial acetic acid $(20 \mathrm{ml})$, and the appropriate aldehyde, namely, benzaldehyde, p-nitrobenzaldehyde, p-methoxybenzaldehyde, 2-thiophenecarboxaldehyde, p-N,N-dimethylaminobenzaldehyde and/or 3,4,5-trimethoxybenzaldehyde (0.002 
mole) was refluxed for 15 hours, cooled, poured into ice/cold water. The precipitate formed was filtered off and recrystallized (cf. Table 3).

\section{2-Substituted amino-7-bromo-6-methyl-8H-pyrano[2,3-e]-benzoxazol-8-one (14a-c)}

A mixture of $\mathbf{1 0}(0.57 \mathrm{gm}, 0.002$ mole $)$ and the appropriate isothiocyanate, namely, ethyl, hexyl and/or phenylisothiocyanate $(0.002 \mathrm{~mole})$ and pyridine $(1 \mathrm{ml})$ in absolute alcohol $(15 \mathrm{ml})$ was refluxed for 24 hours. After cooling, the reaction mixture was poured into ice/cold water, The precipitate formed was filtered off and recrystallized (cf. Table 3).

\section{$N$-Substituted-N`-[3-bromo-7-hydroxy-4-methylcoumarin-8-yl]urea (15a,b)}

A mixture of 10 (0.57 gm, 0.002 mole), phenylisocyanate and/or propylisocyanate $(0.002$ mole) and pyridine $(1 \mathrm{ml})$ in absolute ethanol $(15 \mathrm{ml})$ was refluxed for 30 hours. The reaction mixture was poured into ice/cold water, The precipitate formed was filtered off and recrystallized (cf. Table 3).

\section{7-Bromo-6-methyl-8H-pyrano[2,3-e]benzoxazol-8-one-2-thione (16)}

A mixture of $10(0.57 \mathrm{gm}, 0.002$ mole $)$, potassium hydroxide $(0.46 \mathrm{gm})$ in water $(0.7 \mathrm{ml})$ and carbon disulphide $(0.7 \mathrm{ml})$ in methyl alcohol $(4 \mathrm{ml})$ was refluxed for 24 hours. The excess carbon disulphide was distilled under reduced pressure and the residue was dissolved in water $(10 \mathrm{ml})$ then acidified with acetic acid to $\mathrm{pH} 6$. The precipitate formed was filtered off, washed with water, dried and recrystallized (cf. Table 3).

\section{7-Bromo-6-methyl-2-thio substituted-8H-pyrano[2,3-e]-benzoxazol-8-ones (17a-d)}

A mixture of compound 16 (0.63 gm, 0.002 mole), anhydrous potassium carbonate $(0.5 \mathrm{gm})$, and appropriate alkyl or aryl halide, namely, methyl iodide, allyl chloride, ethyl chloroacetate and/or benzenesulphonyl chloride $(0.002$ mole $)$ in dry acetone $(30 \mathrm{ml})$ was refluxed for 7 hours. The reaction mixture was cooled and poured onto ice/cold water. The precipitate formed was filtered off and recrystallized (cf. Table 3).

\section{8-Bromo-3-chloro-7-methyl-9H-pyrano[2,3-e]benzo-1,4-oxazine-2,9-dione (18)}

A mixture of 10 (0.54 gm, 0.002 mole), dichloroacetyl chloride $(0.2 \mathrm{ml}, 0.002 \mathrm{~mole})$ and anhydrous potassium carbonate $(0.5 \mathrm{gm})$ in dry acetone $(20 \mathrm{ml})$ was refluxed for 10 hours. The reaction mixture was cooled and poured into ice/cold water. The precipitate formed was filtered off and recrystallized (cf. Table 3). 
8-Bromo-7-methyl-9H-pyrano[2,3-e]benzo-1,4-oxazine-2,9-dione (19)

A mixture of 10 (0.54 gm, 0.002 mole $)$, chloroacetyl chloride $(0.17 \mathrm{ml}, 0.002$ mole $)$ and anhydrous potassium carbonate $(0.5 \mathrm{gm})$ in dry acetone $(20 \mathrm{ml})$ was refluxed for 3 hours, cooled then the reaction mixture was cooled and poured into ice/cold water. The precipitate formed was filtered off and recrystallized (cf. Table 3).

8-Bromo-7-methyl-2-substituted-9H-pyrano[2,3-e]benzo-1,4-oxazine-2,9-dione (20a-c)

A mixture of paraformaldehyde $(0.18 \mathrm{gm}, 0.002 \mathrm{~mole})$ and a secondary amine, namely diethylamine, piperidine and/or methylpiperazine $(0.004$ mole $)$ in absolute ethanol $(25 \mathrm{ml})$ was refluxed for 30 minutes, compound 19 (0.62 gm, 0.002 mole) was added and the reaction mixture was refluxed for 24 hours. Ethanol was evaporated under reduced pressure and the residue treated with ether, filtered and recrystallized (cf. Table 3).

Table 2.

\begin{tabular}{|c|c|c|c|c|c|c|}
\hline $\begin{array}{c}\text { Comp. } \\
\text { No. }\end{array}$ & $\begin{array}{c}\text { M.P. } \\
\text { (Solvent } \\
\text { of cryst.) }\end{array}$ & $\begin{array}{c}\text { Yield } \\
\text { \% }\end{array}$ & \multirow{2}{*}{$\begin{array}{c}\text { Molecular } \\
\text { formula } \\
\text { (mol. mass) }\end{array}$} & \multicolumn{3}{|c|}{$\begin{array}{c}\text { Analysis \% } \\
\text { Calcd./Found }\end{array}$} \\
\cline { 5 - 7 } & & & & C & H & N \\
\hline $\mathbf{1 a}$ & 246 & 80 & $\mathrm{C}_{10} \mathrm{H}_{6} \mathrm{BrNO}_{5}$ & 40.02 & 2.01 & 4.66 \\
& (Acetone) & & $(300.04)$ & 39.90 & 2.10 & 5.01 \\
\hline $\mathbf{1 b}$ & 235 & 20 & $\mathrm{C}_{10} \mathrm{H}_{6} \mathrm{BrNO}_{5}$ & 40.02 & 2.01 & 4.66 \\
& (Methanol) & & $(300.04)$ & 39.86 & 2.05 & 4.58 \\
\hline $\mathbf{2}$ & 236 & 70 & $\mathrm{C}_{11} \mathrm{H}_{8} \mathrm{BrNO}_{5}$ & 42.05 & 2.56 & 4.45 \\
& $($ Acetone) & & $(314.07)$ & 42.30 & 2.40 & 4.20 \\
\hline $\mathbf{3}$ & $222-223$ & 68 & $\mathrm{C}_{11} \mathrm{H}_{10} \mathrm{BrNO}_{3}$ & 46.50 & 3.54 & 4.92 \\
& $($ Ethanol) & & $(284.09)$ & 46.85 & 3.92 & 5.21 \\
\hline $\mathbf{4}$ & 276 & 85 & $\mathrm{C}_{13} \mathrm{H}_{11} \mathrm{BrClNO}_{4}$ & 43.30 & 3.07 & 3.88 \\
& $($ Acetone) & & $(360.57)$ & 43.50 & 3.30 & 3.70 \\
\hline $\mathbf{5 a}$ & 211 & 49 & $\mathrm{C}_{18} \mathrm{H}_{21} \mathrm{BrN}_{2} \mathrm{O}_{4} \mathrm{~S}_{2}$ & 45.66 & 4.47 & 5.91 \\
& $($ Ethanol) & & $(473.39)$ & 46.00 & 4.80 & 5.60 \\
\hline $\mathbf{5 b}$ & $156-158$ & 72 & $\mathrm{C}_{19} \mathrm{H}_{21} \mathrm{BrN}_{2} \mathrm{O}_{4} \mathrm{~S}_{2}$ & 47.01 & 4.36 & 5.77 \\
& $($ Ethanol) & & $(485.40)$ & 46.90 & 4.80 & 5.60 \\
\hline $\mathbf{5 c}$ & $185-186$ & 70 & $\mathrm{C}_{18} \mathrm{H}_{19} \mathrm{BrN}_{2} \mathrm{O}_{5} \mathrm{~S}_{2}$ & 44.35 & 3.92 & 5.74 \\
& $($ Ethanol) & & $(487.37)$ & 44.76 & 4.30 & 5.80 \\
\hline $\mathbf{5 d}$ & $173-175$ & 75 & $\mathrm{C}_{19} \mathrm{H}_{22} \mathrm{BrN}_{3} \mathrm{O}_{4} \mathrm{~S}_{2}$ & 45.60 & 4.43 & 8.39 \\
& $($ Ethanol) & & $(500.41)$ & 45.21 & 4.73 & 8.00 \\
\hline $\mathbf{6}$ & $257-258$ & 72 & $\mathrm{C}_{13} \mathrm{H}_{12} \mathrm{BrNO}_{4}$ & 47.87 & 3.71 & 4.29 \\
& $($ Ethanol) & & $(326.13)$ & 48.20 & 3.90 & 4.60 \\
\hline $\mathbf{7}$ & $178-179$ & 92 & $\mathrm{C}_{15} \mathrm{H}_{14} \mathrm{BrNO}_{5}$ & 48.93 & 3.83 & 3.80 \\
& $($ Ethanol) & & $(368.10)$ & 49.20 & 3.60 & 4.00 \\
\hline
\end{tabular}


Table 3.

\begin{tabular}{|c|c|c|c|c|c|c|}
\hline \multirow[t]{2}{*}{$\begin{array}{l}\text { Comp. } \\
\text { No. }\end{array}$} & \multirow{2}{*}{$\begin{array}{l}\text { M.P. }{ }^{\circ} \mathrm{C} \\
\text { (Solvent } \\
\text { of cryst.) }\end{array}$} & \multirow[t]{2}{*}{$\begin{array}{l}\text { Yield } \\
\%\end{array}$} & \multirow{2}{*}{$\begin{array}{c}\text { Molecular } \\
\text { formula } \\
\text { (mol. mass) }\end{array}$} & \multicolumn{3}{|c|}{$\begin{array}{l}\text { Analysis \% } \\
\text { Calcd./Found }\end{array}$} \\
\hline & & & & $\mathrm{C}$ & $\mathrm{H}$ & $\mathrm{N}$ \\
\hline 8 & $\begin{array}{c}144-146 \\
\text { (Ethanol) }\end{array}$ & 77 & $\begin{array}{c}\mathrm{C}_{18} \mathrm{H}_{14} \mathrm{BrNO}_{3} \\
(372.19)\end{array}$ & $\begin{array}{l}58.08 \\
57.73\end{array}$ & $\begin{array}{l}3.79 \\
3.40\end{array}$ & $\begin{array}{l}3.76 \\
3.30\end{array}$ \\
\hline 9 & $\begin{array}{c}101-102 \\
\left(\mathrm{EtOH} / \mathrm{H}_{2} \mathrm{O}\right)\end{array}$ & 63 & $\begin{array}{c}\mathrm{C}_{14} \mathrm{H}_{15} \mathrm{BrN}_{2} \mathrm{O}_{3} \mathrm{~S} \\
(371.24)\end{array}$ & $\begin{array}{l}45.29 \\
45.30 \\
\end{array}$ & $\begin{array}{l}4.07 \\
4.10 \\
\end{array}$ & $\begin{array}{l}7.54 \\
7.30 \\
\end{array}$ \\
\hline 10 & $\begin{array}{c}\text { 260-dec. } \\
\left(\mathrm{MeOH} / \mathrm{H}_{2} \mathrm{O}\right)\end{array}$ & 60 & $\begin{array}{c}\mathrm{C}_{10} \mathrm{H}_{8} \mathrm{BrNO}_{3} \\
(270.06) \\
\end{array}$ & $\begin{array}{l}44.47 \\
44.50 \\
\end{array}$ & $\begin{array}{l}2.98 \\
3.10 \\
\end{array}$ & $\begin{array}{l}5.18 \\
5.30 \\
\end{array}$ \\
\hline 11 & $\begin{array}{l}\text { 238-dec. } \\
\text { (ethanol) }\end{array}$ & 60 & $\begin{array}{c}\mathrm{C}_{11} \mathrm{H}_{8} \mathrm{BrN}_{3} \mathrm{O}_{2} \\
(294.09)\end{array}$ & $\begin{array}{l}44.92 \\
44.80 \\
\end{array}$ & $\begin{array}{l}2.74 \\
2.70 \\
\end{array}$ & $\begin{array}{l}14.28 \\
14.20 \\
\end{array}$ \\
\hline 12 & $\begin{array}{c}290 \\
\text { (ethanol) } \\
\end{array}$ & 55 & $\begin{array}{c}\mathrm{C}_{11} \mathrm{H}_{6} \mathrm{BrNO}_{4} \\
(296.05) \\
\end{array}$ & $\begin{array}{l}44.62 \\
44.50 \\
\end{array}$ & $\begin{array}{l}2.04 \\
2.30 \\
\end{array}$ & $\begin{array}{l}4.72 \\
4.90 \\
\end{array}$ \\
\hline $13 a$ & $\begin{array}{c}>300 \\
\left(\mathrm{DMF} / \mathrm{H}_{2} \mathrm{O}\right)\end{array}$ & 30 & $\begin{array}{c}\mathrm{C}_{12} \mathrm{H}_{8} \mathrm{BrNO}_{3} \\
(294.08) \\
\end{array}$ & $\begin{array}{l}49.00 \\
48.72 \\
\end{array}$ & $\begin{array}{l}2.74 \\
3.11 \\
\end{array}$ & $\begin{array}{l}4.76 \\
4.39 \\
\end{array}$ \\
\hline $13 b$ & $\begin{array}{c}233 \\
\left(\mathrm{DMF} / \mathrm{H}_{2} \mathrm{O}\right)\end{array}$ & 52 & $\begin{array}{c}\mathrm{C}_{14} \mathrm{H}_{8} \mathrm{BrNO}_{5} \\
(350.10)\end{array}$ & $\begin{array}{l}48.02 \\
47.70\end{array}$ & $\begin{array}{l}2.30 \\
2.60\end{array}$ & $\begin{array}{l}3.99 \\
4.38\end{array}$ \\
\hline $13 \mathrm{c}$ & $\begin{array}{c}230 \\
\left(\mathrm{DMF} / \mathrm{H}_{2} \mathrm{O}\right)\end{array}$ & 45 & $\begin{array}{c}\mathrm{C}_{14} \mathrm{H}_{10} \mathrm{BrNO}_{5} \\
(352.12)\end{array}$ & $\begin{array}{l}47.75 \\
47.52 \\
\end{array}$ & $\begin{array}{l}2.86 \\
2.40 \\
\end{array}$ & $\begin{array}{l}3.97 \\
3.62 \\
\end{array}$ \\
\hline 13d & $\begin{array}{c}284 \\
\left(\mathrm{DMF} / \mathrm{H}_{2} \mathrm{O}\right) \\
\end{array}$ & 75 & $\begin{array}{c}\mathrm{C}_{18} \mathrm{H}_{10} \mathrm{BrNO}_{5} \\
(400.16)\end{array}$ & $\begin{array}{l}54.02 \\
54.40 \\
\end{array}$ & $\begin{array}{l}2.51 \\
2.50 \\
\end{array}$ & $\begin{array}{l}3.49 \\
3.90 \\
\end{array}$ \\
\hline $13 \mathrm{e}$ & $\begin{array}{c}>300 \\
\left(\mathrm{DMF} / \mathrm{H}_{2} \mathrm{O}\right)\end{array}$ & 60 & $\begin{array}{c}\mathrm{C}_{18} \mathrm{H}_{9} \mathrm{BrN}_{2} \mathrm{O}_{7} \\
(445.17)\end{array}$ & $\begin{array}{l}48.56 \\
48.84 \\
\end{array}$ & $\begin{array}{l}2.03 \\
2.41 \\
\end{array}$ & $\begin{array}{l}6.29 \\
6.70 \\
\end{array}$ \\
\hline $13 f$ & $\begin{array}{c}\text { 204-206 } \\
\text { (EtOAc/ } \\
\text { pet. ether) }\end{array}$ & 48 & $\begin{array}{c}\mathrm{C}_{17} \mathrm{H}_{10} \mathrm{BrNO}_{3} \\
(356.15)\end{array}$ & $\begin{array}{l}57.32 \\
57.20\end{array}$ & $\begin{array}{l}2.83 \\
3.02\end{array}$ & $\begin{array}{l}3.93 \\
3.50\end{array}$ \\
\hline $13 \mathrm{~g}$ & $\begin{array}{c}216 \\
\text { (EtOAc/ } \\
\text { pet. ether) } \\
\end{array}$ & 86 & $\begin{array}{c}\mathrm{C}_{17} \mathrm{H}_{9} \mathrm{BrN}_{2} \mathrm{O}_{5} \\
(401.16)\end{array}$ & $\begin{array}{l}50.89 \\
50.62\end{array}$ & $\begin{array}{l}2.26 \\
2.43\end{array}$ & $\begin{array}{l}6.98 \\
6.72\end{array}$ \\
\hline 13h & $\begin{array}{c}240 \\
\text { (EtOAc/ } \\
\text { pet. ether) }\end{array}$ & 30 & $\begin{array}{c}\mathrm{C}_{18} \mathrm{H}_{12} \mathrm{BrNO}_{4} \\
(386.18)\end{array}$ & $\begin{array}{l}55.97 \\
55.63\end{array}$ & $\begin{array}{l}3.13 \\
3.52\end{array}$ & $\begin{array}{l}3.62 \\
3.40\end{array}$ \\
\hline $13 \mathbf{i}$ & $\begin{array}{c}217 \\
\text { (EtOAc/ } \\
\text { pet. ether) }\end{array}$ & 35 & $\begin{array}{c}\mathrm{C}_{15} \mathrm{H}_{8} \mathrm{BrNO}_{3} \mathrm{~S} \\
(362.17)\end{array}$ & $\begin{array}{l}49.74 \\
49.31\end{array}$ & $\begin{array}{l}2.22 \\
2.27\end{array}$ & $\begin{array}{l}3.86 \\
3.60\end{array}$ \\
\hline $13 \mathbf{j}$ & $\begin{array}{l}\text { 223-224 } \\
\text { (EtOAc/ } \\
\text { pet. ether) }\end{array}$ & 70 & $\begin{array}{c}\mathrm{C}_{19} \mathrm{H}_{15} \mathrm{BrN}_{2} \mathrm{O}_{3} \\
(399.23)\end{array}$ & $\begin{array}{l}57.15 \\
56.82\end{array}$ & $\begin{array}{l}3.78 \\
3.60\end{array}$ & $\begin{array}{l}7.01 \\
6.76\end{array}$ \\
\hline
\end{tabular}


Continuation of the Table 3.

\begin{tabular}{|c|c|c|c|c|c|c|}
\hline \multirow[t]{2}{*}{$\begin{array}{l}\text { Comp. } \\
\text { No. }\end{array}$} & \multirow{2}{*}{$\begin{array}{l}\text { M.P. }{ }^{0} \mathrm{C} \\
\text { (Solvent } \\
\text { of cryst.) }\end{array}$} & \multirow[t]{2}{*}{$\begin{array}{l}\text { Yield } \\
\%\end{array}$} & \multirow{2}{*}{$\begin{array}{c}\text { Molecular } \\
\text { formula } \\
\text { (mol. mass) }\end{array}$} & \multicolumn{3}{|c|}{$\begin{array}{c}\text { Analysis \% } \\
\text { Calcd./Found }\end{array}$} \\
\hline & & & & C & $\mathbf{H}$ & $\mathbf{N}$ \\
\hline 13k & $\begin{array}{c}201 \\
\text { (EtOAc/ } \\
\text { pet. ether) } \\
\end{array}$ & 55 & $\begin{array}{c}\mathrm{C}_{20} \mathrm{H}_{16} \mathrm{BrNO}_{6} \\
(446.23)\end{array}$ & $\begin{array}{l}53.82 \\
53.51\end{array}$ & $\begin{array}{l}3.61 \\
3.50\end{array}$ & $\begin{array}{l}3.13 \\
3.52\end{array}$ \\
\hline $14 a$ & $\begin{array}{c}273-275 \\
\text { (benzene) }\end{array}$ & 86 & $\begin{array}{c}\mathrm{C}_{13} \mathrm{H}_{11} \mathrm{BrN}_{2} \mathrm{O}_{3} \\
(323.14)\end{array}$ & $\begin{array}{l}48.31 \\
48.12\end{array}$ & $\begin{array}{l}3.43 \\
3.26\end{array}$ & $\begin{array}{l}8.67 \\
8.40\end{array}$ \\
\hline $14 \mathrm{~b}$ & $\begin{array}{c}267 \\
\text { (benzene) }\end{array}$ & 87 & $\begin{array}{c}\mathrm{C}_{17} \mathrm{H}_{17} \mathrm{BrN}_{2} \mathrm{O}_{3} \\
(377.23)\end{array}$ & $\begin{array}{l}54.12 \\
54.19 \\
\end{array}$ & $\begin{array}{l}4.54 \\
4.96 \\
\end{array}$ & $\begin{array}{l}7.42 \\
7.17 \\
\end{array}$ \\
\hline $14 c$ & $\begin{array}{c}190 \\
\text { (benzene) } \\
\end{array}$ & 71 & $\begin{array}{c}\mathrm{C}_{17} \mathrm{H}_{11} \mathrm{BrN}_{2} \mathrm{O}_{3} \\
(371.18) \\
\end{array}$ & $\begin{array}{l}55.00 \\
54.63 \\
\end{array}$ & $\begin{array}{l}2.98 \\
2.52 \\
\end{array}$ & $\begin{array}{l}7.54 \\
7.82 \\
\end{array}$ \\
\hline $15 a$ & $\begin{array}{c}\text { 206-dec } \\
\text { (benzene) }\end{array}$ & 53 & $\begin{array}{c}\mathrm{C}_{17} \mathrm{H}_{13} \mathrm{BrN}_{2} \mathrm{O}_{4} \\
(389.19)\end{array}$ & $\begin{array}{l}52.46 \\
52.10 \\
\end{array}$ & $\begin{array}{l}3.36 \\
3.00 \\
\end{array}$ & $\begin{array}{l}7.19 \\
7.49 \\
\end{array}$ \\
\hline $15 b$ & $\begin{array}{c}196 \\
\text { (benzene/pet } \\
\text { ether) }\end{array}$ & 60 & $\begin{array}{c}\mathrm{C}_{14} \mathrm{H}_{15} \mathrm{BrN}_{2} \mathrm{O}_{4} \\
(355.18)\end{array}$ & $\begin{array}{l}47.33 \\
47.50\end{array}$ & $\begin{array}{l}4.25 \\
4.45\end{array}$ & $\begin{array}{l}7.88 \\
8.13\end{array}$ \\
\hline 16 & $\begin{array}{c}281-2 \\
\text { (ethanol) }\end{array}$ & 85 & $\begin{array}{c}\mathrm{C}_{11} \mathrm{H}_{6} \mathrm{BrNO}_{3} \mathrm{~S} \\
(312.11)\end{array}$ & $\begin{array}{l}42.32 \\
41.90 \\
\end{array}$ & $\begin{array}{l}1.93 \\
2.00\end{array}$ & $\begin{array}{l}4.48 \\
4.10\end{array}$ \\
\hline $17 \mathbf{a}$ & $\begin{array}{c}200 \\
\text { (ethanol) }\end{array}$ & 87 & $\begin{array}{c}\mathrm{C}_{12} \mathrm{H}_{8} \mathrm{BrNO}_{3} \mathrm{~S} \\
(326.14)\end{array}$ & $\begin{array}{l}44.18 \\
44.50 \\
\end{array}$ & $\begin{array}{l}2.47 \\
2.80\end{array}$ & $\begin{array}{l}4.29 \\
4.30 \\
\end{array}$ \\
\hline $17 b$ & $\begin{array}{c}\text { 134-136 } \\
\text { (ethanol-ether) }\end{array}$ & 55 & $\begin{array}{c}\mathrm{C}_{14} \mathrm{H}_{10} \mathrm{BrNO}_{3} \mathrm{~S} \\
(352.18) \\
\end{array}$ & $\begin{array}{l}47.74 \\
47.60 \\
\end{array}$ & $\begin{array}{l}2.86 \\
3.10 \\
\end{array}$ & $\begin{array}{l}3.97 \\
4.00 \\
\end{array}$ \\
\hline $17 \mathrm{c}$ & $\begin{array}{c}175-177 \\
\text { (ethanol-ether) }\end{array}$ & 40 & $\begin{array}{c}\mathrm{C}_{15} \mathrm{H}_{12} \mathrm{BrNO}_{5} \mathrm{~S} \\
(398.21)\end{array}$ & $\begin{array}{l}45.23 \\
45.60 \\
\end{array}$ & $\begin{array}{l}3.03 \\
3.00 \\
\end{array}$ & $\begin{array}{l}3.51 \\
3.90 \\
\end{array}$ \\
\hline 17d & $\begin{array}{r}\text { 204-dec } \\
\text { (ethanol) }\end{array}$ & 57 & $\begin{array}{c}\mathrm{C}_{17} \mathrm{H}_{10} \mathrm{BrNO}_{5} \mathrm{~S}_{2} \\
(452.27)\end{array}$ & $\begin{array}{l}45.14 \\
45.50 \\
\end{array}$ & $\begin{array}{l}2.22 \\
2.00 \\
\end{array}$ & $\begin{array}{l}3.09 \\
3.50 \\
\end{array}$ \\
\hline 18 & $\begin{array}{c}254 \\
\text { (ethanol) } \\
\end{array}$ & 95 & $\begin{array}{c}\mathrm{C}_{12} \mathrm{H}_{7} \mathrm{BrClNO}_{4} \\
(344.52) \\
\end{array}$ & $\begin{array}{l}41.83 \\
41.80 \\
\end{array}$ & $\begin{array}{l}2.04 \\
2.40 \\
\end{array}$ & $\begin{array}{l}4.06 \\
4.00 \\
\end{array}$ \\
\hline 19 & $\begin{array}{c}275 \\
\text { (ethanol) } \\
\end{array}$ & 88 & $\begin{array}{c}\mathrm{C}_{12} \mathrm{H}_{8} \mathrm{BrNO}_{4} \\
(310.08)\end{array}$ & $\begin{array}{l}46.47 \\
46.10 \\
\end{array}$ & $\begin{array}{l}2.59 \\
3.00 \\
\end{array}$ & $\begin{array}{l}4.51 \\
4.88 \\
\end{array}$ \\
\hline $20 a$ & $\begin{array}{c}193 \\
\text { (EtOH/pet. } \\
\text { ether) }\end{array}$ & 44 & $\begin{array}{c}\mathrm{C}_{17} \mathrm{H}_{19} \mathrm{BrN}_{2} \mathrm{O}_{4} \\
(395.24)\end{array}$ & $\begin{array}{l}51.65 \\
51.91\end{array}$ & $\begin{array}{l}4.84 \\
4.61\end{array}$ & $\begin{array}{l}7.08 \\
7.30\end{array}$ \\
\hline $20 b$ & $\begin{array}{c}182 \\
\text { (ethanol) } \\
\end{array}$ & 46 & $\begin{array}{c}\mathrm{C}_{18} \mathrm{H}_{19} \mathrm{BrN}_{2} \mathrm{O}_{4} \\
(407.25)\end{array}$ & $\begin{array}{l}53.08 \\
53.27 \\
\end{array}$ & $\begin{array}{l}4.70 \\
4.54 \\
\end{array}$ & $\begin{array}{l}6.88 \\
7.20 \\
\end{array}$ \\
\hline $20 c$ & $\begin{array}{l}225-226 \\
\text { (ethanol) }\end{array}$ & 49 & $\begin{array}{c}\mathrm{C}_{18} \mathrm{H}_{20} \mathrm{BrN}_{3} \mathrm{O}_{4} \\
(422.26)\end{array}$ & $\begin{array}{l}51.19 \\
50.83 \\
\end{array}$ & $\begin{array}{l}4.77 \\
4.52 \\
\end{array}$ & $\begin{array}{l}9.95 \\
9.80\end{array}$ \\
\hline
\end{tabular}




\section{References and Notes}

1. Soine, T.O. J. Pharm. Sci. 1964, 53, 231.

2. Badran, M.M.; Ismail, M.M.; El-Hakeem, M.A. Egypt. J. Pharm. Sci. 1992, 33, 1081.

3. El-Farargy, A.F. Egypt. J. Pharm. Sci. 1991, 32, 625.

4. Tunek, H. Monatsh. 1962, 93, 684.

5. Nofal, Z.M.; El-Masry, A.H.; Fahmy, H.H.; Sarhan, A.I. Egypt. J. Pharm. Sci. 1997, 38, 1.

6. Kitagawa, H.; Iwaki, R. Yakugaku Zasshi 1958, 78, 491. (Chem. Abstr. 1958, 52, 18874c-d.)

7. Vogel, A.I. Practical Organic Chemistry; Longmans, Green and Co: London, 1976; p 736.

8. Nabih, I.; Michael, J.; Zoorob, H.; El-Zahar, M. Egypt. J. Chem. 1986, 26, 3.

9. Propp, F. J. Med. Chem. 1964, 7, 210.

10. Schouberg, A.; Latif, N. J. Am. Chem. Soc. 1954, 76, 6208.

11. Mannich, C.; Honig, P. Arch. Pharm. 1927, 265, 298.

12. El-Merzabani, M.M.; El-Aaser, A.A.; Attia, M.A.; El-Duweini, A.; Ghazal, A.M. J. Planta Medica 1979, 36, 150.

13. Lazarus, H.; Tegeler, M.; Mazzone, H.; Le Roy, J.; Boone, B.; Foley, G.; Cancer Chemother-Rep. 1966, 50, 543.

Samples Availability: available from MDPI.

(C) 2000 by MDPI (http://www.mdpi.org). Reproduction is permitted for noncommercial purposes. 